\title{
Pemanfaatan Gas Buang Blast Furnace Plant Menggunakan Top-Gas Recovery Turbine (TRT) Sebagai Upaya Penghematan Energi
}

\author{
Tjatur Udjianto ${ }^{1}$, Teguh Sasono ${ }^{2}$ \\ Jurusan Teknik Konversi Energi, Politeknik Negeri Bandung,Indonesia \\ email : tjatur_te@yahoo.com, teguhssn@gmail.com
}

\begin{abstract}
Abstrak
Energi telah menjadi kebutuhan mendasar dan sebagai salah satu komponen biaya di dalam industri salah satunya pabrik baja terpadu. Salah satu upaya untuk untuk mengurangi biaya produksi tanpa mempengaruhi hasil atau kualitas produksi adalah dengan memanfaatkan gas buang yang dihasilkan dari proses yang terdapat di pabrik baja terpadu. Salah satu gas buang yang dihasilkan adalah blast furnace gas (BFG) yang dihasilkan dari proses di Blast Furnace Plant. Salah satu cara untuk menurunkan konsumsi energi Listrik Khususnya di Blast furnace plant adalah dengan diaplikasikannya Top-gas Recovery Turbine (TRT). TRT merupakan suatu sistem yang dapat membangkitkan energi listrik dengan memanfaatkan gas buang yang dihasilkan dari bagian atas (top) Blast furnace yang dialirkan melalui Gas cleaning plant untuk selanjutnya memutarkan turbin-generator. Dengan adanya sistem TRT ini, BFG dapat dimanfaatkan secara maksimal dan dapat menambah pasokan listrik sehingga bisa mengurangi biaya energi listrik. Berdasarkan hasil perhitungan kapasitas terpasang TRT adalah sebesar $18 \mathrm{MW}$. Energi listrik yang dihasilkan adalah sebesar 117.121,5 MWh. Estimasi jumlah penghematan biaya listrik adalah sebesar 120,12 milyar/tahun. Dengan adanya TRT pengurangan emisi $\mathrm{CO}_{2}$ dalam satu tahun adalah sebesar 84,064 ton- $\mathrm{CO}_{2}$
\end{abstract}

Kata Kunci TRT, blast furnace gas, penghematan, emisi $\mathrm{CO}_{2}$

\section{PENDAHULUAN}

Energi telah menjadi kebutuhan mendasar dan sebagai salah satu komponen biaya di dalam industri salah satunya pabrik baja terpadu. Salah satu upaya untuk untuk mengurangi biaya produksi tanpa mempengaruhi hasil atau kualitas produksi adalah dengan memanfaatkan gas buang yang dihasilkan dari proses yang terdapat di pabrik baja terpadu. Salah satu gas buang yang dihasilkan adalah blast furnace gas (BFG) yang dihasilkan dari proses di Blast furnace plant.

Blast Furnace Plant merupakan tempat produksi hot metal (besi cair) melalui proses peleburan dan reduksi bijih besi sintered ore, pellet serta lump ore. Proses peleburan dan reduksi tersebut menggunakan batubara dan coke sebagai sumber bahan bakar peleburan dan sumber gas pereduksi.

BFG yang dihasilkan adalah sekitar $60 \%$ dari total gas buang yang dihasilkan pabrik baja terpadu. Gas buang tersebut masih memiliki manfaat untuk digunakan kembali dalam proses produksi, maupun dengan kandungan energinya dapat dimanfaatkan kembali untuk menghasilkan energi listrik. Dengan memanfaatkan gas buang menjadi energi lsitrik diharapkan dapat menurunkan biaya energi serta menurunkan emisi $\mathrm{CO}_{2}$.

Untuk memanfaatkan BFG tersebut sebelum digunakan untuk pembangkit sebagai bahan bakar ataupun diumpankan kembali dalam proses produksi, tekanan dan suhu dari BFG tersebut dapat dimanfaatkan untuk menghasilkan listrik dengan diaplikasikannya Top-gas Recovery Turbine (TRT). Dengan adanya sistem TRT ini, Gas buang dapat dimanfaatkan secara maksimal dan Dapat menambah pasokan listrik sehingga bisa mengurangi biaya energi listrik, khususnya pada Blast furnace plant.

Penelitian ini ditujukan khusus untuk menganalisis penghematan yang dapat dilakukan dengan diaplikasikannya sistem TRT Khususnya pada Blast furnace plant serta estimasi penurunan emisi $\mathrm{CO}_{2}$.
Tujuan dari penelitian ini adalah melakukan kajian pemanfaatan BFG pada proses peleburan di Blast furnace plant. Dengan dipasangnya TRT ini dapat dihitung dan dianalisis peluang penghematan energi listrik serta penurunan emisi $\mathrm{CO}_{2}$. Manfaat yang didapatkan dari hasil penelitian ini adalah diharapkan hasil penelitian dapat digunakan sebagai referensi dan bahan kajian untuk penelitian tentang TRT lebih lanjut.

\section{TINJAUAN PUSTAKA}

BFG merupakan gas buang yang dihasilkan pada proses peleburan besi di Blast furnace plant. Gas buang ini memiliki tekanan dan suhu tertentu yang bisa dimanfaatkan sebelum digunakan untuk proses produksi atau dibakar di pembangkit captive power. Besarnya potensi daya yang terkandung dalam BFG dapat dihitung dengan menggunakan persamaan berikut ini [3].

$P=Q \times D \times C_{p} \times T_{1} \times\left\{1-(p 2 / p 1)^{\left(n-\frac{1}{n}\right)}\right\} \times \eta_{T} \times \eta_{G}$

\section{Dengan:}

P: Daya output $(\mathrm{kcal} / \mathrm{s})$
$\mathrm{Q}$ : laju aliran gas buang $\left(\mathrm{Nm}^{3} / \mathrm{detik}\right)$
$\mathrm{Cp}:$ Panas spesifik gas buang $\left(\mathrm{kJ} / \mathrm{kg} .{ }^{\circ} \mathrm{K}\right)$
$\mathrm{T}_{1}$ : Suhu masuk TRT, $\left({ }^{\circ} \mathrm{K}\right)$
$\mathrm{p}_{1}$ : Tekanan masuk TRT, $(\mathrm{bar})$
$\mathrm{p}_{2}$ : Tekanan keluar TRT, (bar)
$\mathrm{n}$ : eksponen ekspansi adiabatik
$\eta_{\mathrm{T}}$ : Efisiensi turbin, $(\%)$
$\eta_{\mathrm{G}}:$ Efisiensi generator, $(\%)$.

Beberapa studi tentang TRT, Blast furnace plant dan penentuan daya output TRT maupun sistem TRT yang terpasang telah banyak dipublikasikan. Terdapat beberapa penelitian yang dijadikan referensi oleh peneliti. Menurut [3] TRT digunakan untuk memanfaatkan energi tekanan dari Blast furnace gas yang 
merupakan produk sampingan dari Blast furnace plant. Daya yang dihasilkan dari Blast furnace gas adalah seperti yang ditunjukan pada persamaan (1) tersebut di atas.

Dengan dipasangnya TRT, listrik yang dihasilkan dapat digunakan kembali sekitar 25-30\% dari kebutuhan total listrik Blast furnace plant [3]. Daya yang dihasilkan oleh TRT akan tergantung dari fluktuasi BFG yang dihasilkan di bagian atas furnace. Parameter perubahan tekanan, suhu dan debit masuk kedalam TRT berpengaruh terhadap produksi daya TRT.

Menurut [6], Teknologi TRT adalah merupakan salah satu teknologi hijau yang merupakan teknologi bersih dan efisien. TRT terdiri dari turbin ekspansi dengan mekanisme pengendalian tekanan yang dikopel langsung dengan generator. Pada sistem TRT ini tidak terjadi pembakaran sehingga tidak menghasilkan emisi $\mathrm{CO}_{2}$.

Sedangkan [2] memberikan penjelasan mengenai teknologi yang digunakan di pabrik besi dan baja yang dapat menghemat penggunaan energi dan menurunkan emisi $\mathrm{CO}_{2}$, salah satunya teknologi TRT. Bahwa dengan dipasangnya TRT dapat menghemat listrik sebesar 0,49GJ/t-pig iron dan menurunkan emisi $\mathrm{CO}_{2}$ sebesar $25 \mathrm{~kg}-\mathrm{CO}_{2} / \mathrm{t}$-pig iron.

Penelitian ini akan menyajikan pembahasan mengenai estimasi perhitungan daya yang dapat dihasilkan dari BFG pada salah satu pabrik baja di Indonesia. Selain itu juga akan dihitung penghematan listrik yang didapatkan karena dipasangnya TRT serta estimasi pengurangan emisi $\mathrm{CO}_{2}$. Perhitungan daya yang dihasilkan oleh TRT akan menggunakan persamaan seperti pada referensi [3].

\section{II.1 Blast Furnace Plant}

Proses pada Blast furnace merupakan proses produksi besi cair melalui proses peleburan dan reduksi bijih besi sintered ore, pellet, dan lump ore. Proses peleburan dan reduksi tersebut menggunakan batubara dan coke sebagai sumber bahan bakar peleburan dan sumber gas pereduksi.

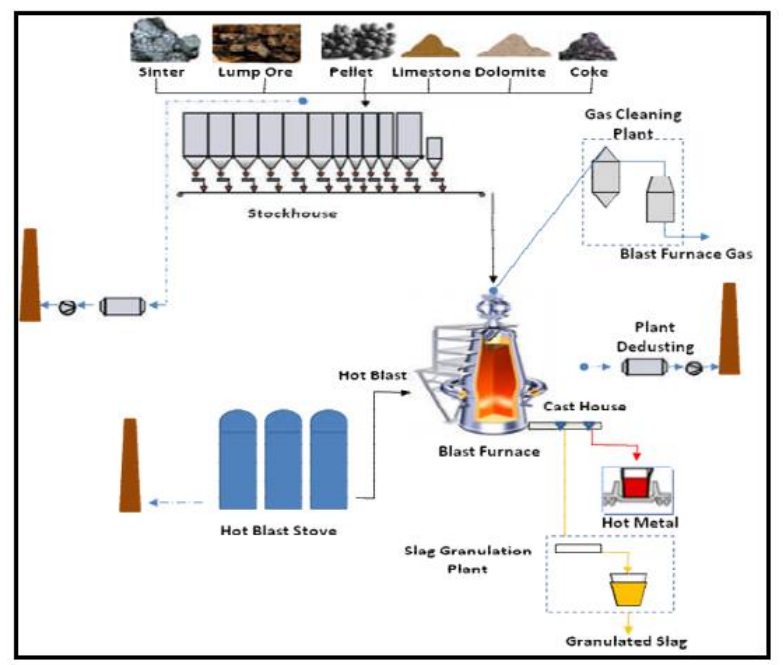

Gambar 1 Skema Blast furnace plant (sumber: data sekunder pabrik baja)

Fasilitas utama yang terdapat pada Blast furnace plant adalah sebagai berikut:

\section{Stockhouse}

Stockhouse digunakan untuk penyimpanan sementara bahan baku, fluks, dan coke sebelum diumpankan ke Blast furnace. Peralatan yang terdapat pada Stockhouse antara lain: storage silo, screen, weighing feeder, dan belt conveyor system.

\section{Furnace Proper}

Furnace proper berfungsi sebagai tempat terjadinya proses reduksi dan peleburan bahan baku. Peralatan yang terdapat pada Furnace Proper antara lain: charging system, water cooled panel, PCI injection system, dan peralatan instrumentasi seperti pengukuran suhu dan komposisi gas.

\section{Hot Blast Stove}

Hot blast stove berfungsi untuk memanaskan udara sampai dengan suhu di atas $1.200^{\circ} \mathrm{C}$ sebelum udara tersebut dihembuskan ke dalam Furnace proper. Peralatan yang terdapat pada Hot blast stove antara lain blower, oxygen injection system, burner, dan refraktori.

\section{Cast House}

Cast house merupakan tempat yang digunakan untuk mengeluarkan produk dari Blast furnace berupa besi cair dan slag yang dihasilkan. Peralatan yang terdapat pada Cast house meliputi tap hole drilling machine, mud gun, hot metal \& slag runner, runner cover, tilting runner dan ladle sebagai tempat penampungan besi cair.

\section{Slag Granulation Plant}

Slag granulation plant berfungsi untuk proses granulasi slag yang dihasilkan selama proses peleburan di Blast furnace dengan menyemprotkan air ke slag yang keluar melalui slag runner. Peralatan yang terdapat pada Slag granulation plant adalah water spray system dan slag dewatering system.

\section{Gas Cleaning Plant}

Gas cleaning plant berfungsi untuk menyaring kotoran (debu) yang terdapat pada gas hasil reaksi di dalam reaktor. Peralatan yang terdapat pada Gas cleaning plant adalah siklon, peralatan control tekanan gas dan pipa gas. Gas yang telah dibersihkan di Gas cleaning plant digunakan sebagai bahan bakar pada Hot blast stove dan pembangkit termasuk TRT.

\section{Pig Iron Casting Machine}

Pig iron casting machine berfungsi untuk mengolah pig iron dari Blast furnace bila terdapat masalah pada Steel making plant yang tidak dapat menerima produk dari Blast furnace. Peralatan yang ada pada Pig iron casting machine antara lain Settling tank, Pump house, Line preparation unit dan Pig storage yard yang dilengkapi dengan Crane magnet.

\section{II.2 Top Gas Recovery Turbine (TRT)}

TRT merupakan suatu sistem yang dapat membangkitkan energi listrik dengan memanfaatkan gas buang yang dihasilkan dari bagian atas (top) Blast furnace yang dialirkan melalui Gas cleaning plant untuk selanjutnya memutarkan turbin-generator. Selanjutnya BFG yang keluar dari TRT tersebut disalurkan menuju gas holder dan digunakan sebagai bahan bakar untuk pembangkit captive power dan juga sebagian digunakan untuk proses produksi di Steel making plant. BFG yang dihasilkan Blast furnace mempunyai spesifkasi tekanan sekitar $0,2-0,236 \mathrm{MPa}\left(2-2,41 \mathrm{~kg} / \mathrm{cm}^{2}\right)$ dan suhu sekitar $200^{\circ} \mathrm{C}$ pada titik cerobong bagian atas (top) dari blast furnace. TRT ini memanfaatkan debit, suhu dan tekanan BFG untuk memutarkan turbin-generator dan menghasilkan listrik.

Secara garis besar, TRT ini terdiri dari peralatan utama yaitu pengumpul debu, turbin gas dan generator. Dalam metoda pengoperasiannya TRT terdiri dari 2 jenis yaitu wet method dan dry method, tergantung dari metode purifikasi yang dilakukan terhadap gas buang BFG. Pada wet method, debu dihilangkan menggunakan ventury scrubber, sedangkan pada dry method debu dihilangkan menggunakan dry-type dust collector. Pada saat menggunakan $d r y$ method, penurunan suhu BFG pada inlet TRT lebih kecil 
dibandingkan dengan wet method dan hasilnya output yang dihasilkan dry method lebih besar maksimum 1,6 kali dibandingkan dengan wet method (NEDO)

Gambaran sistem Blast furnace plant yang dilengkapi dengan TRT dry method dan wet method dapat dilihat pada gambar berikut ini.

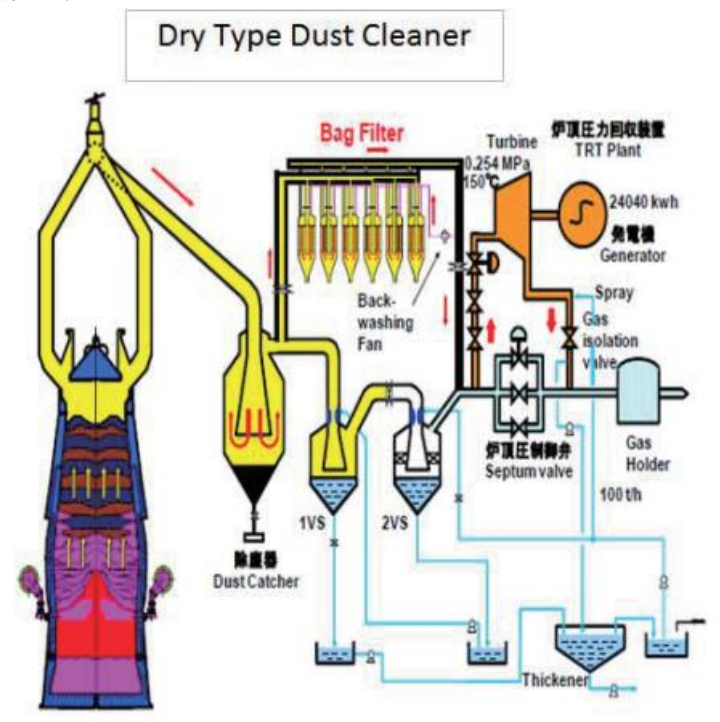

Gambar 2 Blast furnace dengan TRT dry method (NEDO, Jepang)

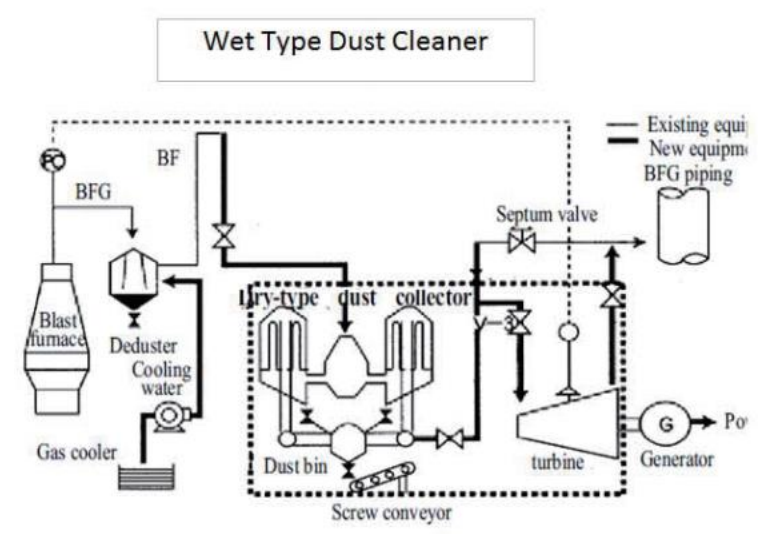

Gambar 3 Blast furnace dengan TRT wet method (NEDO, Jepang)

\subsection{Emisi $\mathrm{CO}_{2}$}

Efek positif yang ditimbulkan akibat dipasangnya TRT pada Blast furnace Plant selain penghematan energi listrik adalah juga penurunan emisi $\mathrm{CO}_{2}$. Perhitungan pengurangan emisi $\mathrm{CO}_{2}$ dengan dipasangnya TRT akan diasumsikan bahwa sebelum di pasang TRT listrik didapatkan dari jaringan listrik PLN. Setelah dipasang TRT, pasokan listrik dari PLN diasumsikan tidak dipakai sebesar energi listrik yang dihasilkan oleh TRT. Perhitungan pengurangan emisi $\mathrm{CO}_{2}$ didapatkan dari perkalian antara energi yang diproduksi dalam setahun dengan faktor emisi $\mathrm{CO}_{2}$ Jaringan PLN pada area pabrik baja.

\section{HASIL DAN PEMBAHASAN}

\section{III.1 Data Survey}

Data sekunder didapatkan dari salah satu pabrik baja terpadu di daerah Cilegon. Data sekunder yang didapatkan adalah berupa karakteristik BFG dan juga termasuk parameter operasi seperti kandungan energi, debit, suhu dan tekanan dari BFG. Data sekunder hasil survei dan pengumpulan dapat dilihat pada tabel di bawah ini. TABEL 1 KARAKTERISTIK BLAST FURNACE GAS

\begin{tabular}{|l|l|}
\hline \multicolumn{2}{|c|}{ Blast Furnace Gas $(\mathrm{BFG})$} \\
\hline Densitas & $1,35 \sim 1,38 \mathrm{~kg} / \mathrm{Nm}^{3}$ \\
\hline Suhu Top Blast Furnace & $200 \sim 250^{\circ} \mathrm{C}$ \\
\hline Lower Heating Value & $750 \mathrm{kCal} / \mathrm{Nm}^{3}$ \\
\hline Dust Content & $10 \mathrm{mg} / \mathrm{Nm}^{3}$ \\
\hline $\mathrm{CO}$ & $20 \%$ \\
\hline $\mathrm{CO}_{2}$ & $20,7 \%$ \\
\hline $\mathrm{H}_{2}$ & $3,2 \%$ \\
\hline $\mathrm{N}_{2}$ & $54,1 \%$ \\
\hline Gas total & $100 \%$ \\
\hline
\end{tabular}

TABEL 2 PARAMETER OPERASI TRT

\begin{tabular}{|l|l|}
\hline Produksi BFG & $3.975 .053 \mathrm{Gcal}$ \\
\hline Debit BFG maksimum & $596.200 \mathrm{Nm}^{3} / \mathrm{jam}$ \\
\hline Suhu masuk TRT & $55^{\circ} \mathrm{C}$ \\
\hline Tekanan masuk TRT & $2,1 \mathrm{~kg} / \mathrm{cm}^{2}$ \\
\hline Tekanan keluar TRT & $0,002 \mathrm{bar}$ \\
\hline
\end{tabular}

\subsection{Skema TRT}

TRT yang terpasang pada pabrik baja di Cilegon berdasarkan pengoperasiannya adalah merupakan jenis wet method, yaitu pada bagian furifikasi gas BFG menggunakan ventury scrubber. Disebut wet method karena pada proses pembersihan gas menggunakan air. Skema TRT dengan pola operasi wet method pada pabrik baja dapat dilihat pada gambar di bawah ini.

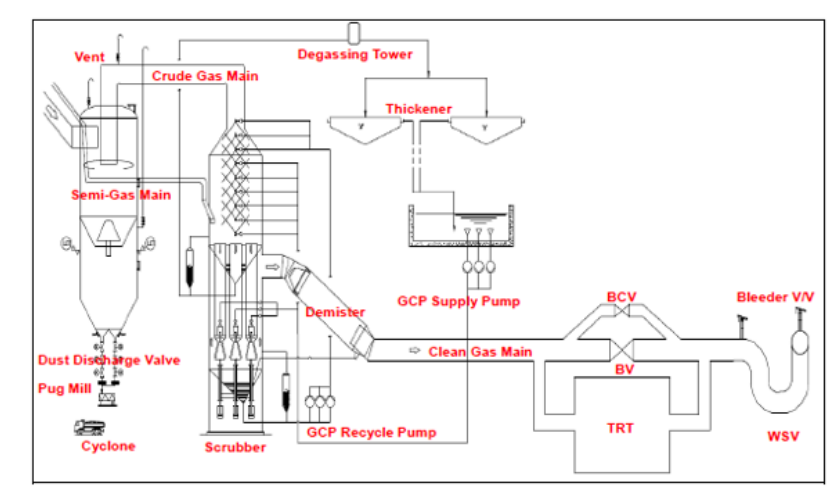

Gambar 4 Skema pemasangan TRT (sumber: data Sekunder pabrik baja)

Cara kerja sistem TRT secara singkat adalah BFG yang dihasilkan Blast furnace pada proses peleburan biji besi disalurkan menuju siklon untuk memisahkan material debu yang terbawa oleh BFG. Selanjutnya gas disalurkan menuju ventury scrubber untuk memisahkan partikel debu lebih kecil dan gas terlarut dalam air dengan menggunakan bantuan air atau cairan. Sehingga gas BFG keluar dari ventury scrubber sudah benar-benar bersih. Untuk menghilangkan butir-butir air akibat proses di scrubber, sebelum masuk TRT, BFG dilewatkan terlebih dahulu melalui demister.

BFG yang sudah bersih dari debu dan butiran air selanjutnya dialirkan menuju TRT untuk memutarkan turbin-generator dan menghasilkan listrik. Keluaran dari TRT selanjutnya menuju gas holder untuk dicampur dengan Linz donawitz gas (LDG) dan Coke oven gas (COG) dan disalurkan untuk proses produksi maupun dibakar di pembangkit captive power untuk menghasilkan listrik. Proses yang terjadi pada TRT adalah tidak terjadi pembakaran, hanya memanfaatkan parameter tekanan dan suhu yang terkandung di dalam BFG. 


\section{III.2 Produksi dan Konsumsi BFG}

Selain menghasilkan BFG pabrik baja terpadu juga menghasilkan LDG dan COG sebagai produk sampingan. LDG merupakan produk sampingan dari proses besi cair menjadi baja cair. sedangkan COG merupakan produk sampingan dari proses yang terjadi di Coke oven plant. Ketiga jenis gas tersebut selanjutnya akan digunakan kembali kedalam proses produksi dan sebagian digunakan sebagai bahan bakar captive power. Khusus BFG sebelum digunakan untuk proses produksi maupun captive power terlebih dahulu digunakan untuk memutar turbin generator pada sistem TRT dan menghasilkan listrik.

Dalam proses produksi yang terjadi di pabrik baja, gas BFG yang dihasilkan adalah sebesar 3.975.053 Gcal, sedangkan gas COG sekitar 2.181.359 Gcal dan gas LDG sekitar 356.993 Gcal. Produksi gas BFG adalah sekitar $61,03 \%$ dari toal gas yang dihasilkan pabrik baja. Sedangkan konsumsi gas untuk Blast furnace sendiri sebesar 1.603.690Gcal atau sekitar 24,62\% dari total konsumsi gas pabrik baja. Sisanya sebesar 75,38\% digunakan untuk keperluan gas plant lainnya.

Produksi dan konsumsi BFG, COG dan LDG gas dapat dilihat pada tabel di bahwah ini.

TABEL 3 PRODUKSI DAN KONSUMSI GAS BY PRODUCT PADA PABRIK BAJA

\begin{tabular}{|l|l|c|c|c|}
\hline Nama Unit/Plant & Kriteria & $\begin{array}{c}\text { Uni } \\
\mathbf{t}\end{array}$ & \multicolumn{1}{c|}{ Total } & Persen \\
\hline BFG (gas) & Produksi & $\begin{array}{c}\text { Gca } \\
1\end{array}$ & 3.975 .053 & $61,03 \%$ \\
\hline COG (gas) & Produksi & $\begin{array}{c}\text { Gca } \\
1\end{array}$ & 2.181 .359 & $33,49 \%$ \\
\hline LDG (gas) & Produksi & $\begin{array}{c}\text { Gca } \\
1\end{array}$ & 356.993 & $5,48 \%$ \\
\hline Vendor & Konsumsi & $\begin{array}{c}\text { Gca } \\
1\end{array}$ & 3.208 & $0,05 \%$ \\
\hline $\begin{array}{l}\text { Sales (KPCC, } \\
\text { Lime Calcining) }\end{array}$ & Konsumsi & $\begin{array}{c}\text { Gca } \\
1\end{array}$ & 159.899 & $2,45 \%$ \\
\hline $\begin{array}{l}\text { Sales (KPE, Power } \\
\text { generation) }\end{array}$ & Konsumsi & $\begin{array}{c}\text { Gca } \\
1\end{array}$ & 2.718 .071 & $41,73 \%$ \\
\hline Loss, Diffusion & Konsumsi & $\begin{array}{c}\text { Gca } \\
1\end{array}$ & 489.101 & $7,51 \%$ \\
\hline Sinter Plant & Konsumsi & $\begin{array}{c}\text { Gca } \\
1\end{array}$ & 42.644 & $0,65 \%$ \\
\hline $\begin{array}{l}\text { Blast Furnace } \\
\text { Plant }\end{array}$ & Konsumsi & $\begin{array}{c}\text { Gca } \\
1\end{array}$ & 1.603 .690 & $24,62 \%$ \\
\hline Cokes plant & Konsumsi & $\begin{array}{c}\text { Gca } \\
1\end{array}$ & 1.062 .568 & $16,31 \%$ \\
\hline $\begin{array}{l}\text { Cokes by product } \\
\text { plant }\end{array}$ & Konsumsi & $\begin{array}{c}\text { Gca } \\
1\end{array}$ & & $0,00 \%$ \\
\hline Steel making & Konsumsi & $\begin{array}{c}\text { Gca } \\
1\end{array}$ & 56.502 & $0,87 \%$ \\
\hline $\begin{array}{l}\text { Continuous } \\
\text { Casting }\end{array}$ & Konsumsi & $\begin{array}{c}\text { Gca } \\
1\end{array}$ & 4.059 & $0,06 \%$ \\
\hline Plate plant & Konsumsi & $\begin{array}{c}\text { Gca } \\
1\end{array}$ & 373.663 & $5,74 \%$ \\
\hline
\end{tabular}

\section{III.3Perhitungan Daya TRT}

Perhitungan potensi daya listrik yang dapat dihasilkan oleh TRT adalah dengan menggunakan persamaan (1) dengan memasukan parameter-patameter yang telah didapatkan. Berikut ini adalah asumsi dan parameter yang digunakan dalam perhitungan daya TRT.

- Laju aliran BFG $596.200 \mathrm{Nm}^{3} / \mathrm{jam}$ atau $165,6 \mathrm{Nm}^{3} /$ detik

- Panas spesifik BFG 1,0584 kJ/kg. ${ }^{\circ} \mathrm{K}$ )

- Tekanan BFG masuk TRT 2,2 bar (g)
- $\quad$ Suhu BFG masuk TRT $55^{\circ} \mathrm{C}$

- Tekanan BFG keluar TRT 0,02 bar

- Efisiensi turbin $85 \%$

- Efisiensi generator $97 \%$

Berdasarkan asumsi dan parameter tersebut di atas selanjutnya dilakukan perhitungan menggunakan persamaan (1) tersebut di atas dengan hasil sebagai berikut:

$$
\begin{gathered}
P=165,6 \times 1,38 \times 1,0584 \times 328,15 \times\left\{1-(1 / 3,2)^{\left(1,384-\frac{1}{1,384}\right)}\right\} \\
\times 0,85 \times 0,97 \\
P=18025,37 \mathrm{~kJ} / \mathrm{s}
\end{gathered}
$$

Berdasarkan perhitungan tersebut di atas, daya yang dapat dihasilkan oleh TRT adalah sebesar $18025,37 \mathrm{~kJ} / \mathrm{s}$ atau 18,02MW. Dengan hasil perhitungan tersebut selanjutnya ditetapkan bahwa daya terpasang untuk TRT adalah sebesar 18MW. Pada operasinya, listrik yang dihasilkan oleh TRT akan tergantung dari proses produksi besi cair yang terjadi di Blast furnace plant. Apabila proses produksi besi cair sedang tinggi, maka aliran BFG akan tinggi yang tentunya akan mempengaruhi listrik yang dihasilkan di TRT. Selain itu juga parameter yang terdapat pada BFG akan mempengaruhi produksi listrik seperti tekanan dan suhu yang terkandung di BFG.

Karena kondisi perubahan pola operasi tersebut sepanjang tahun TRT diasumsikan dioperasikan tetap pada faktor kapasitas $85 \%$. Faktor kapasitas ini selanjutnya digunakan sebagai salah satu parameter untuk menghitung produksi energi yang dihasilkan TRT.

\section{III.4 Analisis Produksi Energi}

Perhitungan produksi energi tahunan didapatkan dari jumlah daya listrik terpasang dikalikan dengan jumlah jam operasi dan faktor kapasitas TRT. Karena TRT hanya beroperasi saat Blast furnace plant beroperasi, maka jumlah jam operasi TRT akan sama dengan jumlah jam operasi Blast furnace plant. Berdasarkan data yang didapatkan bahwa jam operasi Blast furnace plant selama satu tahun adalah 7655 jam.

Perhitungan produksi energi dalam satu tahun dengan asumsi dan parameter tersebut di atas didapatkan bahwa produksi energi TRT dalam satu tahun sebesar 117.121,5MWh. Nilai produksi ini masih gross, belum dikurangi kebutuhan auxiliary TRT. Perkiraan kebutuhan beban auxiliary untuk TRT sekitar 1\% dari daya terpasang, sehingga Sehingga energi net yang dihasilkan setelah dikurangi pemakaian sendiri adalah sekitar 115.950MWh.

\section{III.5 Analisis Penghematan Energi}

Analisis penghematan energi didasarkan pada energi yang dihasilkan TRT dan digunakan untuk memenuhi kebutuhan listrik Blast furnace Plant. Menurut [3] Pasokan daya dari TRT dapat digunakan kembali memenuhi sekitar $25-30 \%$ dari total kebutuhan energi listrik blast furnace plant.

Berdasarkan data pabrik, bahwa energi listrik yang dibutuhkan untuk mengoperasikan Blast furnace Plant untuk menghasilkan 1 ton besi cair adalah sebesar $52,7 \mathrm{kWh} /$ ton maka kebutuhan energi listrik dalam satu tahun untuk menghasilkan 3.000.000 besi cair adalah sebesar 158.100 MWh. Perhitungan penghematan energi dengan dipasangnya TRT dapat dilihat pada tabel di bawah ini. 
TABEL 4 PENGHEMATAN ENERGI LISTRIK DENGAN DIPASANGNYA TRT

\begin{tabular}{|l|r|r|}
\hline \multicolumn{1}{|c|}{ Parameter } & \multicolumn{1}{|c|}{ Nilai } & \multicolumn{1}{l|}{ Satuan } \\
\hline Kapasitas Terpasang & 18,0 & MW \\
\hline Operasi & 15,3 & MW \\
\hline $\begin{array}{l}\text { Jam Operasi Blast furnace } \\
\text { plant/jam operasi TRT }\end{array}$ & 7655 & Jam/tahun \\
\hline Produksi listrik TRT & $117.121,5$ & MWh/tahun \\
\hline $\begin{array}{l}\text { Energi untuk Pemakaian } \\
\text { Sendiri }\end{array}$ & 1.171 & MWh/tahun \\
\hline Penghematan listrik & 115.950 & MWh/tahun \\
\hline Produksi Besi cair & 3.000 .000 & ton/tahun \\
\hline $\begin{array}{l}\text { Konsumsi listrik spesifik Blast } \\
\text { furnace plant }\end{array}$ & 52,7 & $\mathrm{kWh/ton}$ \\
\hline Konsumsi listrik per tahun & 158.100 & MWh.tahun \\
\hline $\begin{array}{l}\text { Persentase energi listrik yang } \\
\text { dipasok oleh TRT }\end{array}$ & $73 \%$ & Persen \\
\hline Biaya listrik & 1.036 & Rp/kWh \\
\hline Jumlah Penghematan & 120.124 .495 .260 & Rp/tahun \\
\hline
\end{tabular}

Berdasarkan tabel tersebut di atas, didapatkan bahwa penghematan listrik selama satu tahun adalah sebesar 115.950 MWh. Nilai penghematan ini diasumsikan bahwa semua energi listrik yang dihasilkan TRT diserap kembali oleh Blast furnace Plant. Energi listrik yang dihasilkan TRT mampu untuk memenuhi kebutuhan semua energi listrik Blast furnace plant sebesar $73 \%$. Presentase tersebut jauh di atas kisaran energi yang dapat ditanggung TRT sebesar 25\%-30\% sesuai dengan yang dinyatakan dalam referensi [3]. Hal ini menandakan bahwa konsumsi energi blast furnace plant pabrik baja ini jauh lebih efisiens dan konsumsi energinya jauh lebih kecil dibandingkan dengan pabrik baja pada umumnya. Perbedaan yang sangat besar ini disebabkan karena nilai energi spesifik Blast furnace plant yang sangat kecil sebesar 52,7kWh/ton.

Estimasi penghematan biaya didapatkan dari produksi energi tiap tahun dikalikan biaya listrik PLN per kWh. Berdasarkan perhitungan tersebut, Pemasangan sistem TRT diestimasikan dapat menghemat biaya penggunaan listrik sebesar 120,12 Milyar/tahun.

\section{III.6Perhitungan Reduksi Emisi CO2}

TRT merupakan salah satu teknologi hijau yang bersih dan efisien. Pada TRT dalam proses menghasilkan listrik tindak dilakukan pembakaran sehingga tidak menghasilkan emisi $\mathrm{CO}_{2}$. Dalam analisis ini TRT diasumsikan menggantikan listrik dari jaringan PLN untuk memenuhi kebutuhan energi listrik di blast furnace plant. Metode terhitungan Emisi $\mathrm{CO}_{2}$ mengggunakan faktor emisi yaitu dengan mengalikan jumlah energi terpakai dengan faktor emisi sesuai dengan jaringan kelistrikan wilayah setempat. Faktor emsisi jaringan listrik yang dipakai adalah Jamali dengan nilai $0,725 \mathrm{kgCO}_{2} / \mathrm{kWh}$. Reduksi emisi $\mathrm{CO}_{2}$ karena dipasangnya TRT dalam setahun adalah sebesar 84.064ton- $\mathrm{CO}_{2}$.

\section{KESIMPULAN}

Berdasarkan dari hasil perhitungan dan analisis yang telah dilakukan, didapatkan kesimpulan sebagai berikut:
1. Energi listrik gross yang dihasilkan dalam satu tahun adalah sebesar 117.121,5 MWh. Dengan kebutuhan beban auxiliary TRT sebesar $1 \%$ dari daya terpasang maka produksi energi net yang dihasilkan setelah dikurangi pemakaian sendiri adalah sekitar 115.950 MWh.

2. Karena semua energi listrik yang dihasilkan oleh TRT dipakai semua untuk memasok listrik ke Blast furnace plant, maka besarnya penghematan listrik adalah sama dengan produksi TRT sebesar $115.950 \mathrm{MWh}$.

3. Penghematan listrik yang dapat dilakukan pabrik baja dengan adanya TRT ini adalah sebesar 120,12 milyar/tahun.

4. Estimasi penuruna $\mathrm{CO}_{2}$ dengan dipasangnya TRT pada Blast furnace plant adalah sebesar 84.064ton- $\mathrm{CO}_{2}$ dalam satu tahun.

\section{SARAN}

Untuk penelitian yang akan datang dapat dilanjutkan dengan penelitian yang membahas penghematan yang dapat dilakukan apabila gas BFG tersebut digunakan sebagai bahan bakar captive power dan menghasilkan listrik dan digunakan Bersama dengan TRT untuk memasok kebutuhan listrik pabrik baja.

\section{DAFTAR PUSTAKA}

[1] Hasanbeigi, A., Cardenas, J. C., Price, L., Triolo, R., \& Arens, M. (2015). Comparison of Energy-Related Carbon Dioxide Emissions Intensity of the International Iron and Steel Industry: Case Studies from China, Germany, Mexico, and the United States. California: Lawrence Berkeley National Laboratory.

[2] LBNL. (2010). The State-of-the-Art Clean Technologies (SOACT) for Steelmaking Handbook (2nd Edition). California.

[3] Priya, S. S., \& Patil, R. G. (2014). BF Gas Utilization and Power Generation in Steel Plant Using TRT. International Journal of Mechanical And Production Engineering, 79-82.

[4] Tan, X., \& Seligsoh, D. (2011). Efficiency in The Steel Sector . Journal of the Washington Institute of China Studies, 59-74.

[5] Tanakaa, K., Matsuhashib, R., \& Kudoa, M. N. (2006). CO2 Reduction Potential by Energy Efficient Technology in Energy Intensive Industry. Institute of Energy Economics Japan, 1-13.

[6] Tiwari, M., Ahmad, S., \& Alam, S. (2017). Production Of Green Steel through Green Manufacturing using Most Innovative Green and Cleaner Technology . International Journal of Engineering Sciences \& Research Technology , 668-676. 